\title{
Frequency of staphylococcal lysozyme production tested by plate method ${ }^{1}$
}

\author{
J. HAWIGER
}

From the Department of Bacteriology, State Institute of Hygiene, Warsaw, Poland

SYNOPSIS Lysozyme production is a frequent property of staphylococcal strains isolated from various sources; all 503 tested strains of Staphylococcus aureus and 13 out of 35 strains of Staphylococcus epidermidis produced an enzyme lysing Micrococcus lysodeikticus as tested by a modified plate method. Lysozyme production by staphylococci is more frequent than the production of free coagulase, clumping factor, staphylokinase, Tween 80 lipase, and $\mathrm{HgCl}_{2}$ resistance.

The staphylococcal lysozyme produced by Staphylococcus aureus strain 524 is an enzyme by which living cells and the cell walls of Micrococcus lysodeikticus are lysed. Its action results in the appearance of degradation products of the cell walls, which react as $\mathrm{N}$-acetylamino sugars and contain free reducing groups (Richmond, 1959). The staphylococcal lysozyme also acts on murein isolated from cell walls of the producing strain, as well as on cell walls of Staphylococcus epidermidis. A number of properties of staphylococcal lysozyme have been determined (Hawiger, 1968) and compared with those of crystalline egg white lysozyme (E.C. 3.2.1.17 mucopeptide $\mathrm{N}$-acetylmuramyl hydrolase). The two enzymes exhibit some similarities.

It seemed to be of interest to determine by uniform methods the incidence of lysozyme production by staphylococci isolated mainly from pathological cases. For comparative purposes the determination included also the production of some agents important in the differentiation of staphylococci recently isolated in epidemiological work (Jevons, John, and Parker, 1966). On the other hand, for practical reasons it was decided to evaluate the possibility of lysozyme determination by the plate method in the routine diagnosis of staphylococci.

\section{MATERIAL AND METHODS}

STAPHYLOCOCCAL STRAINS The following strains were tested: 143 strains obtained from the territorial sanitary epidemiological stations, where they were isolated from current diagnostic specimens collected from patients;

${ }^{1}$ This study was supported by a grant CDC-LP-3 from the Communicable Diseases Center, U.S. Public Health Service.

Received for publication 21 September 1967.
175 strains isolated from burnt patients admitted to hospital in the Clinic of Surgery, Institute of Haematology, Warsaw, were obtained by courtesy of Dr. Serafinska and Dr. Zak; 182 strains from the collection of this laboratory, including standard strains for phages, standard strains with stable antigenic properties used for preparing immune sera (Cowan I, II, III, Oeding's strains); classic strains used for isolating individual staphylococcal toxins and enzymes (Newman, Wood $\left.46, \mathrm{~V}-8, \mathrm{E}_{7}, 524\right)$; enterotoxic strains, strains of animal origin; strain $502 \mathrm{~A}$; and 43 strains isolated in routine diagnostic work in this laboratory.

IDENTIFICATION OF STRAINS All the strains of Grampositive cocci were identified according to the principles and methods recommended in Cowan's and Steel's manual (Cowan and Steel, 1965). Catalase, glucose oxidation, and fermentation (OF test), mannitol fermentation, and the production of free coagulase and clumping factor were determined.

The properties of the strains were determined as follows: staphylokinase production was determined by the plate method (Lack and Wailling, 1955); the production of Tween 80-splitting lipase was tested by the plate method (Sierra, 1952); $\mathrm{HgCl}_{2}$ resistance was determined by the plate method (Moore, 1960).

DETERMINATION OF STAPHYLOCOCCAL LYSOZYME PRODUCTION BY THE MODIFIED PLATE METHOD A suspension of M. lysodeikticus cells killed by heat is present in the medium. After solidification of the medium, which becomes opaque, staphylococcal strains are inoculated on it. During incubation at $37^{\circ} \mathrm{C}$ zones of transparency appear around the growing colonies, due to lysis of M. lysodeikticus cells by lysozyme produced by the growing strain.

Medium The medium for determining lysozyme production is that of Goldbach and Haenel (1964). Take $0.4 \%$ yeast extract, $0.6 \%$ glucose, and $0.1 \%$ Tween 80 made up to $100 \%$ with nutrient agar $(\mathrm{pH}=6 \cdot 8)$. 


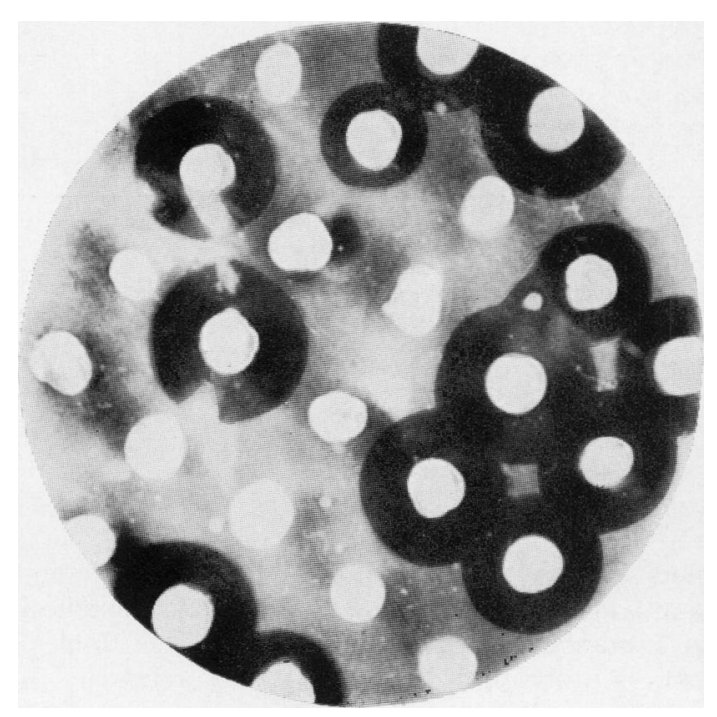

FIG. 1. Lysozyme production by staphylococci on solid medium containing heat-killed Micrococcus lysodeikticus cells. Transparent zones around growing sirains indicate lysis of substrate.

Preparation of the substrate (M. lysodeikticus suspension) $M$. lysodeikticus strain Fleming was obtained from the Strain Collection, State Institute of Hygiene, and grown on Smolelis and Hartsell medium (Smolelis and Hartsell, 1949).

The bacterial suspension was autoclaved $(15 \mathrm{~min}, 1$ atm) and, after cooling, added to the liquefied medium to make a final concentration of about $10^{3}$ cells per millilitre of the medium. The medium was poured on Petri plates $10 \mathrm{~cm}$ in diameter and, after solidification, the plates were dried for two hours at $37^{\circ} \mathrm{C}$; they could be stored for several days in a refrigerator.

PROCEDURE The medium was inoculated with a drop of six-hour broth culture of each of the strains tested; 20 to 25 drops were put on one plate. Readings were made for the first time after 24 hours' incubation at $37^{\circ} \mathrm{C}$, and a second time after 48 hours. Lysozymeproducing strains were surrounded by a transparent zone, which was best visible in a dark background. A test plate with the strains tested and with zones visible around some of them is illustrated in Figure 1.

DETERMINATION OF STAPHYLOCOCCAL LYSOZYME PRODUCTION BY TEST TUBE METHOD The procedure was based on the method reported by Kashiba, Niizu, Tanaka, Nosu, and Amano (1959) as described in another paper (Hawiger, 1968).

The strains tested were inoculated into test tubes with Difco brain-heart infusion medium and incubated for 24 hours at $37^{\circ} \mathrm{C}$ on a shaking machine. The activity of the lysozyme produced was determined in the supernatant by adding $2 \mathrm{ml}$ to $2 \mathrm{ml}$ of the substrate $(M$. lysodeikticus standard suspension) and calculating the percentage of the optical density (index of lysis) at $550 \mathrm{~m} \mu$ wavelength. A reduction in the optical density of the M. lysodeikticus standard suspension higher than $10 \%$ was accepted as a positive result, indicating the effect of lysozyme.

\section{RESULTS}

A total of 543 strains was tested, including 503 strains of $S$. aureus, 35 strains of $S$. epidermidis, and five strains of cocci not belonging to the genus Staphylococcus (catalase + glucose fermentation in the OF test); the latter were eliminated from further analysis. They produced no lysozyme. Lysozyme was produced by all $S$. aureus strains, irrespective of their origin. Among $35 \mathrm{~S}$. epidermidis strains, 13 produced lysozyme. Strains found to produce no lysozyme by the plate method were negative also by the test tube method.

In the set of strains tested, the production of several staphylococcal agents was compared, namely, free coagulase, clumping factor, staphylokinase, Tween 80 -lipase, and lysozyme. $\mathrm{HgCl}_{2}$ resistance, was also determined. The results are presented in Table I.

TABLE I

LYSOZYME PRODUCTION COMPARED WITH OTHER PROPERTIES OF THE STAPHYLOCOCCI TESTED

Oirgin of Strains

Lysozyme-producing Strains

Non-lysozyme-producing Strains

\begin{tabular}{lllllllllll}
\hline Total & $\begin{array}{l}\text { Free } \\
\text { Coagulase }\end{array}$ & $\mathrm{Bc}$ & $\begin{array}{l}\text { Staphy- } \\
\text { lokinase }\end{array}$ & $\begin{array}{l}\text { Tween } \\
80 \text { Lipase }\end{array}$ & $\mathrm{HgCl}_{2}$ & Resistance & Total & Free & $\mathrm{Bc}$ & $\begin{array}{l}\text { Staphy- } \\
\text { lokinase }\end{array}$
\end{tabular}

Sanitary-epidemiological

stations

(routine diagnosi:

Clinic of Surgery

(bun patients)

Collection at this

laboratory 171

Routine diagnostic work

of this laboratory

Total

Coagulase

lokinase 80 Lipase Resistance

lokinase 80 Lipase Resistance 
TABLE II

INCIDENCE OF LYSOZYME PRODUCTION BY STAPHYLOCOCCI

\begin{tabular}{|c|c|c|c|c|c|}
\hline \multirow[t]{2}{*}{ Author } & \multicolumn{2}{|l|}{ S. aureus } & \multicolumn{2}{|c|}{ S. epidermidis } & \multirow[t]{2}{*}{ Other Properties Tested } \\
\hline & $\begin{array}{l}\text { Lysozyme } \\
(+)\end{array}$ & $\begin{array}{l}\text { Lysozyme } \\
(-)\end{array}$ & $\begin{array}{l}\text { Lysozyme } \\
(+)\end{array}$ & $\begin{array}{l}\text { Lysozyme } \\
(-)\end{array}$ & \\
\hline $\begin{array}{l}\text { Welsch (1959) } \\
\text { Kashiba et al. (1959) } \\
\text { Omori et al. (1960) } \\
\text { Goldbach and Haenel } \\
\text { Jay (1966) }\end{array}$ & $\begin{array}{r}30 \\
55 \\
133 \\
82 \\
120\end{array}$ & $\frac{-}{-}$ & $\begin{array}{r}- \\
11 \\
3 \\
15 \\
4\end{array}$ & $\begin{array}{r}- \\
31 \\
200 \\
28 \\
45\end{array}$ & $\begin{array}{l}\text { Sensitivity to leukozyme A } \\
\text { Protease } \\
\text { Egg yolk factor } \\
\text { Rabbit haemolysin } \\
\text { Sheep haemolysin }\end{array}$ \\
\hline Total & 420 & 6 & 33 & 304 & \\
\hline $\begin{array}{l}\text { Material tested in } \\
\text { the present study }\end{array}$ & 503 & - & 13 & 22 & $\begin{array}{l}\text { Staphylokinase, Tween-80 lipase, } \\
\mathrm{HgCl}_{2} \text { resistance }\end{array}$ \\
\hline
\end{tabular}

Out of 516 lysozyme-producing strains, free coagulase was produced by $484(93 \%)$, clumping factor by $483(93 \%)$, staphylokinase by $410(79 \%)$, lipase by $248(48 \%)$ strains, and $249(48 \%)$ strains were resistant to $\mathrm{HgCl}_{2}$. Among 22 strains producing no lysozyme, only two produced lipase.

\section{DISCUSSION}

A total of 426 coagulase-positive strains had been tested by all the authors who reported lysozyme production by staphylococci. The material tested in the present study included 503 coagulase-positive strains. A comparison of the results obtained with data reported by various other authors (Table II) suggests a significant coincidenceas regards lysozyme production by $S$. aureus.

Almost beyond doubt, lysozyme is produced by all strains of this species. The question of lysozyme production by coagulase-negative strains remains controversial. According to the taxonomic criteria valid for $S$. epidermidis, especially in view of the existence of many other coagulase-negative cocci, strains were collected of which about one third were lysozyme-producing staphylococci. This quantity is in accordance with the percentage reported by Goldbach and Haenel (1964), who tested a similar total number of strains, and a little higher than the data reported by Kashiba et al. (1959). It should be mentioned that lysozyme production was determined under similar conditions in the present study and in that reported by Goldbach and Haenel, while Kashiba et al. determined it in broth culture by the test tube method.

The applied plate method of lysozyme determination appeared to be convenient and rapid for detecting this enzyme in staphylococci. Of the strains found to produce no lysozyme in the plate method, none produced it under the conditions of liquid culture in brain-heart infusion. As compared with the test tube method, the plate method has a number of advantages. It is easier to perform. Autolysin, which might be released in staphylococcal cultures, is not a source of difficulty, for its production is very low in solid medium (Ralston, Lieberman, Baer, and Krueger, 1957). $M$. lysodeikticus autolytic enzymes also do not interfere in the determination by the plate method, being inactivated by higher temperatures before testing.

Lysozyme production seems to be a property more frequent than $\mathrm{HgCl}_{2}$ resistance and the production of free and bound coagulase, staphylokinase, and lipase. None of the agents, except coagulase, has been previously tested comparatively with lysozyme. Except for two lipaseproducing strains, lysozyme-negative strains do not produce other agents tested.

It is not clear why lysozyme is produced by some $S$. epidermidis strains. According to Japanese authors (Kashiba et al., 1959), most coagulasenegative and lysozyme-producing strains are resistant to leukozyme $\mathrm{A}$, and thus have a chance of surviving inside leukocytes. On the other hand, Jay's results (Jay, 1966) suggest that coagulasenegative strains isolated from cases of subacute endocarditis, infections of the urinary tract, and wounds produce no lysozyme although they are considered pathogenic. Unfortunately, resistance of these strains to leukozyme A was not tested by Jay so that final conclusions are not possible.

Beyond doubt lysozyme production by staphylococci is more frequent than the production of coagulase and other agents. It can be determined under the conditions of routine bacteriological diagnosis; colonies producing no lysozyme are unlikely to be coagulase positive, but the reverse does not hold and all lysozyme producers must be tested further for evidence of potential pathogenicity. 
The author is greatly indebted to Mrs. Józefa Budzynowska and Mrs. Bogumita Kluz for technical assistance.

\section{REFERENCES}

Cowan, S. 'T., and Steel K. J. (1965). Manual for the Identification of Medical Bacteria. Cambridge University Press, London.

Goldbach, W, and Haenel H. (1964). Zbl. Bakt., I. Abt. Orig., 195, 201.

Hawiger, J. (1968). J. Bact. 95, 376.

Jay, J. M. (1966). Ibid., 91, 1804.
Jevons, M. P., John, M., and Parker, M. T. (1966). J. clin. Path., 19, 305.

Kashiba, S., Niizu, K., Tanaka, S., Nozu, H., and Amano, T. (1959). Biken's J., 2, 50.

Lack, C. H., and Wailling, D. G. (1954). J. Path. Bact., 68, 431. Moore, B. (1960). Lancet, 2, 453.

Omori, G., Kato, K., and Iida, S. (1960). Osaka Cy med. J., 6, 33. Ralston, D. J., Liebermann, M., Baer, B., and Krueger, A. P. (1957). J. gen. Physiol., 40, 791.

Richmond, M. H. (1959). Biochim. biophys. Acta (Amst.), 31, 564. Sierra, G. (1957). Antonie V. Leeuwenhoek, 23, 15.

Smolelis, A. N., and Hartsell, S. E. (1949). J. Bact., 58, 731.

Welsch, M. (1959). C. R. Soc. Biol. (Paris), 153, 2080. 